Revue bibliographique pour le domaine irano-aryen

\title{
Ran Zadok. "West Semitic Groups in the Nippur Region between c. 750 and 330 B.C.E."
}

\section{Astrid Nunn}

\section{(2) OpenEdition}

1 Journals

\section{Édition électronique}

URL : http://journals.openedition.org/abstractairanica/45461

DOI : 10.4000/abstractairanica.45461

ISBN : 1961-960X

ISSN : 1961-960X

Éditeur :

CNRS (UMR 7528 Mondes iraniens et indiens), Éditions de l'IFRI

Référence électronique

Astrid Nunn, "Ran Zadok. "West Semitic Groups in the Nippur Region between c. 750 and 330 B.C.E." », Abstracta Iranica [En ligne], Volume 37-38-39 | 2018, document 42, mis en ligne le 30 décembre 2018, consulté le 26 septembre 2020. URL : http://journals.openedition.org/abstractairanica/45461 DOI : https://doi.org/10.4000/abstractairanica.45461

Ce document a été généré automatiquement le 26 septembre 2020

Tous droits réservés 


\section{Ran Zadok. "West Semitic Groups in the Nippur Region between c. 750 and 330 B.C.E."}

\section{Astrid Nunn}

\section{RÉFÉRENCE}

Ran Zadok. "West Semitic Groups in the Nippur Region between c. 750 and 330 B.C.E." in Jonathan Stökl, Caroline Waerzeggers (eds.). Exile and Return. The Babylonian Context. Berlin: de Gruyter, 2015, p. 94-157.

1 L'A. rassemble des informations sur des groupes ethno-linguistiques des Chaldéens, Araméens et Arabes originaires de l'ouest mais habitant Nippur. Suivent des considérations sur l'intégration de minorités ethniques en Babylonie. L'A. passe en revue le nom des tribus en se basant sur les textes cunéiformes des différentes époques, les archives de Murašû étant la source la plus importante pour l'époque achéménide. Les Babyloniens ne semblent pas avoir encouragé le processus d'assimilation. Cependant, les fonctionnaires haut-placés qu'étaient les juges et les scribes (de l'alphabet) ainsi que l'élite des étrangers, hormis celle des Judéens, se sont tout de même assimilés. D'autres sémites de l'ouest sont serviteurs, boulangers, tanneurs, pâtres, bateliers, ils fabriquaient des parchemins ou encore alimentaient les chevaux. Cet article évocateur indique aussi que les Araméens sont, contrairement aux Egyptiens par exemple, très peu représentés dans les échelons supérieurs de la société. 


\section{AUTEURS}

\section{ASTRID NUNN}

Université de Munich 